\title{
Statistical analysis for lithogeophysical maps using airborne gamma-ray spectrometry
}

Jessica Derkacz Weihermann a, Fabrício Rodrigues Castro a, Luís Gustavo de Castro a, Francisco José Fonseca Ferreira a, Saulo Pomponet Oliveira a ${ }^{a}$, Adalene Moreira Silva ${ }^{b}$.

a Federal University of Paraná, ${ }^{b}$ University of Brasília

Copyright 2019, SBGf - Sociedade Brasileira de Geofísica

This paper was prepared for presentation during the $16^{\text {th }}$ International Congress of the Brazilian Geophysical Society held in Rio de Janeiro, Brazil, 19-22 August 2019.

Contents of this paper were reviewed by the Technical Committee of the $16^{\text {th }}$ International Congress of the Brazilian Geophysical Society and do not necessarily represent any position of the SBGf, its officers or members. Electronic reproduction or storage of any part of this paper for commercial purposes without the written consent of the Brazilian Geophysical Society is prohibited.

\section{Abstract}

Airborne gamma-ray spectrometry (AGRS) is a useful tool for geological mapping, mineral exploration, and geomorphological studies. The variations observed in AGRS data are typically used to differentiate geological units. Usually, AGRS is used to construct lithogeophysical maps, which are based on the interpretation of a ternary map. We propose a Matlab program for interpreting AGRS data, based on a methodology adopted, mainly, by the Geological Survey of Brazil, which facilitates the data manipulation and minimizes the interpreter bias. This methodology is based in a statistical analysis performed through each radioelement dataset, subdividing it into subsets of low, mean, and high values which are combined three-bythree to generate the lithogeophysical classes. We choose an area to test the proposed methodology located near Mara Rosa, Goiás, Brazil.

\section{Introduction}

Gamma-ray spectrometry is widely used for surface geological mapping (e.g., Graham \& Bonham-Carter 1993; Charbonneau et al. 1997). Lithogeophysical maps are constructed considering a ternary map for enhancing the radioelement patterns within individual rock units, for this is taken into account the interpreter's experience and acuity.

The AGRS method measures the relative abundance or concentration of potassium $(\mathrm{K})$, uranium $(\mathrm{eU})$ and thorium (eTh) in rocks and weathered materials up to $30-45 \mathrm{~cm}$ deep by detecting the gamma radiation emitted by the natural radioactive decay of these elements (Dickson \& Scott, 1997; Minty, 1997; Wilford et al., 1997; Wilford, 2002; IAEA, 2003). The main sources of gamma radiation are derived from the disintegration of potassium $40\left({ }^{40} \mathrm{~K}\right)$, uranium $238\left({ }^{238} \mathrm{U}\right)$ and thorium $232\left({ }^{232} \mathrm{Th}\right)$ series.

We tested the proposed methodology in an area located in the State of Goiás (Fig.1), inserted in the Aerogeophysical Project Mara Rosa Magmatic Arc (CPRM 2004), according to figure 1. The Mara Rosa Magmatic Arc is inserted in the geological framework of the Tocantins Province, which corresponds to an expressive Neoproterozoic (Brasiliano / Pan-African) orogenic zone. The Brasília Belt, which comprises mainly a thick metasedimentary sequence, occupies the province eastern portion and a large area

where juvenile Neoproterozoic arc rocks are exposed (Goiás Magmatic Arc) (Silva et al., 2007).

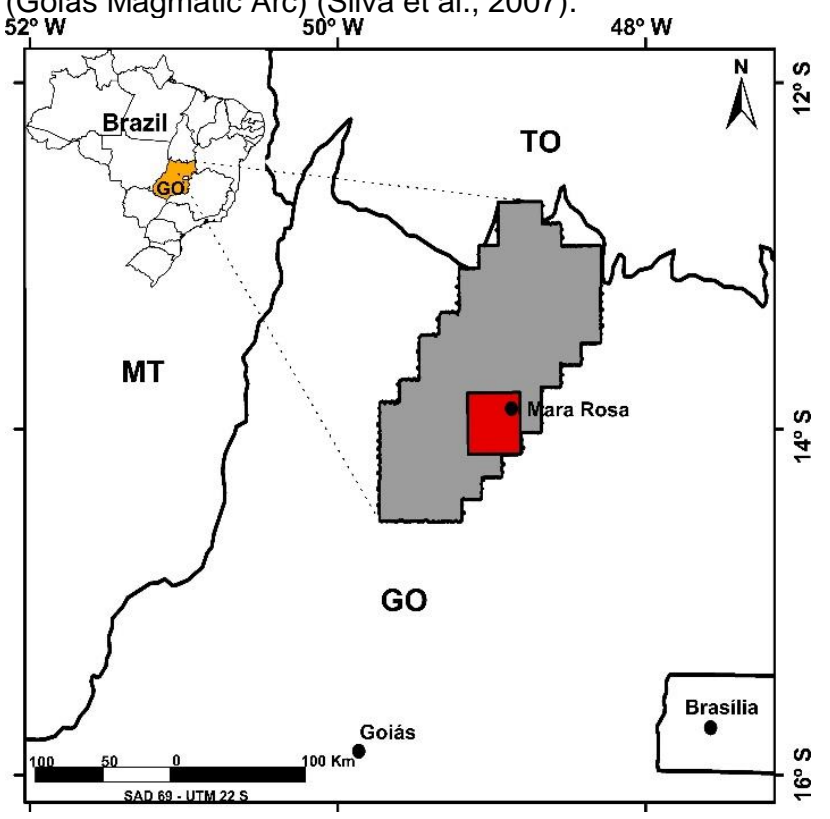

Figure 1 - Location of the study area in red, indicating the geophysical project in grey.

The Goiás Magmatic Arc is a Neoproterozoic crustal accretion, subdivided in Arenópolis Arc and Mara Rosa Arc, southern and northern portions, respectively (Pimentel 2016).

The Mara Rosa Magmatic Arc consists of elongated volcano-sedimentary belts with NNE direction, individualized by orthogneisses with predominantly tonalitic (Arantes et al. 1991, Pimentel et al. 1997). The supracrustal sequences include an expressive volume of mafic metavolcanic rocks, in addition to intermediate to felsic representatives, intercalated with metasedimentary rocks of detrital and chemical nature. The mineral paragenesis with granada, staurolite and cyanite indicate conditions of metamorphism in the greenschist to amphibolite facies (Della Giustina 2007).

Important mineral deposits in the central region of Brazil are associated with hydrothermalism, such as those of the Mara Rosa Magmatic Arc (Chapada, Posse, Zacarias and Mundinho) (Fig. 2). The gamma-ray spectrometry allows the investigation of mineral deposits associated to potassic hydrothermal alterations.

\section{Method}

The present methodology (e.g. Oliveira 2018) consists in interpreting gamma-ray spectrometric data, based on a statistical analysis. The statistical method uses the limits of 
the lithogeophysical classes to delimit the domains eliminating the interpreter bias.

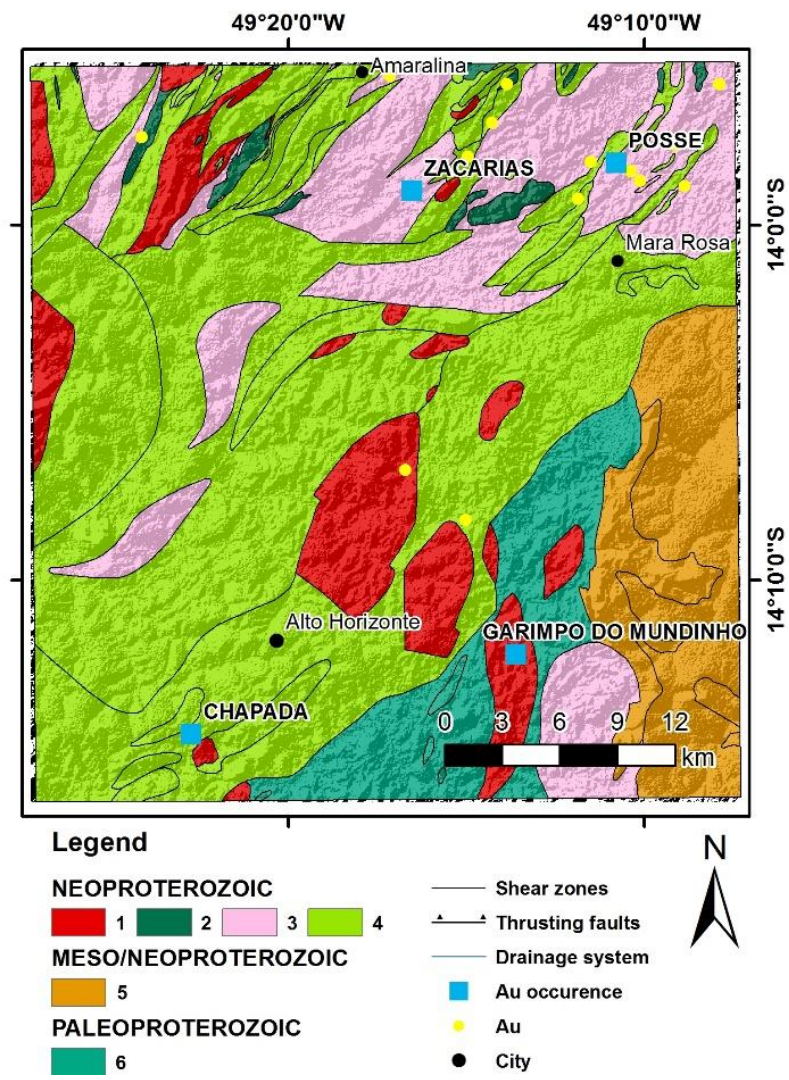

Figure 2 - Geological map of the study area. 1 - Sin-Pos tectonic granites; 2- Gabbro-diorite; 3 - Orthogneiss-Biotite gneiss; 4 - Mara Rosa Volcano-Sedimentary Sequence; 5 Serra da Mesa Group; 6 - Campinorte VolcanoSedimentary Sequence.

The statistical analysis starts with the evaluation of the airborne gamma-ray spectrometry database. The database is composed of three datasets, related to each radioelement channel, for instance, $\mathrm{K}$, eTh and eU channels.

The classes delimitation for each radioelement is based on mean and standard deviation where the high $(\mathrm{H})$, medium (M) and low (L) values are established for each radioelement. As a result, are obtained nine georeferenced subsets, $\mathrm{K}$ (high, medium and low), eTh (high, medium and low) and eU (high, medium and low). The value combination of the three elements results in twenty-seven classes according to figure 3 . Each dataset is subdivided into three subsets based on two statistical limits.

The low subset is limited by the lowest value of the respective radioelement and by the mean minus one standard deviation. The medium subset is limited between the mean minus one standard deviation and the mean plus one standard deviation, and the high subset is limited by the mean plus one standard deviation and the highest value of the respective radionuclide (Table 1).

In order to automate the described process, we used a MATLAB graphical user interface named as LGM Lithogeophysical Maps. The LGM is inserted in the GRAV-
MAG SUITE (Castro et al. 2018), which could be used to process potential field data.

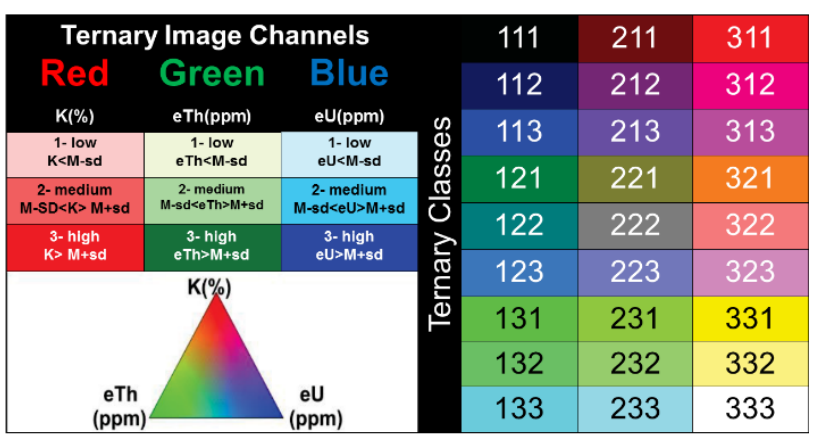

Figure 3 - Statistical analysis of ternary classes (adapted from Oliveira 2018).

Table 1 - Radioelements statistical classification of the study area ( $\overline{\boldsymbol{x}} .=$ mean; $\boldsymbol{S D}=$ standard deviation).

\begin{tabular}{|l|c|c|c|}
\hline Radioelement & $\overline{\boldsymbol{x}}-\boldsymbol{S D}$ & $\overline{\boldsymbol{x}}$ & $\overline{\boldsymbol{x}}+\boldsymbol{S D}$ \\
\hline $\mathbf{K}$ & 1,19 & 1,93 & 2,67 \\
\hline $\mathbf{e U}$ & 2,58 & 3,42 & 4,26 \\
\hline eTh & 4,11 & 10,08 & 16,06 \\
\hline
\end{tabular}

The LGM program separately processes the AGRS data for each radioelement and then combines the products in a single map. In the following we describe how each element $(\mathrm{K}, \mathrm{eTh}, \mathrm{eU})$ is individually processed.

The first step is to format the gridded concentrations as a matrix with positive values:

$$
\mathbf{P}=\left[\begin{array}{ccc}
\mathrm{p}_{11} & \cdots & \mathrm{p}_{1 \mathrm{n}} \\
\vdots & \ddots & \vdots \\
\mathrm{p}_{\mathrm{m} 1} & \cdots & \mathrm{p}_{\mathrm{mn}}
\end{array}\right],
$$

where $p_{i j}>0$ is the concentration at the grid point $x_{i j}$ (negative values are set to 0 ). From matrix $\mathbf{P}$ we generate three binary matrices $\mathbf{P}_{1}, \mathbf{P}_{2}$ and $\mathbf{P}_{3}$, whose components are 1 if the concentration is low, medium or high, respectively, and 0 otherwise.

From these matrices, obtained for each radioelement, we define the combined matrices (2)

$$
\mathbf{P}_{i j l}=\mathbf{P}_{i}^{K} * \mathbf{P}_{j}^{e T h} * \mathbf{P}_{l}^{e U},
$$

where the multiplication is performed component wise. For example $\mathbf{P}_{121}=\mathbf{P}_{1}^{K} \mathbf{P}_{2}^{e T h} \mathbf{P}_{1}^{e U}$. We generate all ternary combinations indicated in figure 3 , resulting in 27 matrices.

The generation of the 27 lithogeophysical classes is computed automatically by the program, which presents the result in the form of a map that can be exported in the shapefile ( $\left.{ }^{*} . \mathrm{shp}\right)$ format. The boundaries marking the transition from 1 to 0 values define the shape of the lithogeophysical classes polygons.

\section{Results and Discussion}

Firstly, we have processed the data of the Mara Rosa Project (CPRM 2004) resulting in potassium, thorium, uranium and ternary maps (Fig. 4).

The use of LGM program is relatively simple; the program opens a user interface, which requests the gridded concentrations of the three radioelements $(\mathrm{K}, \mathrm{eTh}$, eU). 
The grids must be corrected with values $\geq 0.01$, never zero, otherwise the program will not work.

The statistical analysis favors the database manipulation; however, it presents limitations that must be considered. When the high, medium and low subgroups are defined, the neighboring concentrations are arbitrarily separated.

The RGB color pattern was used to represent the lithofacies (K-eTh-eU). The red, green and blue colors are
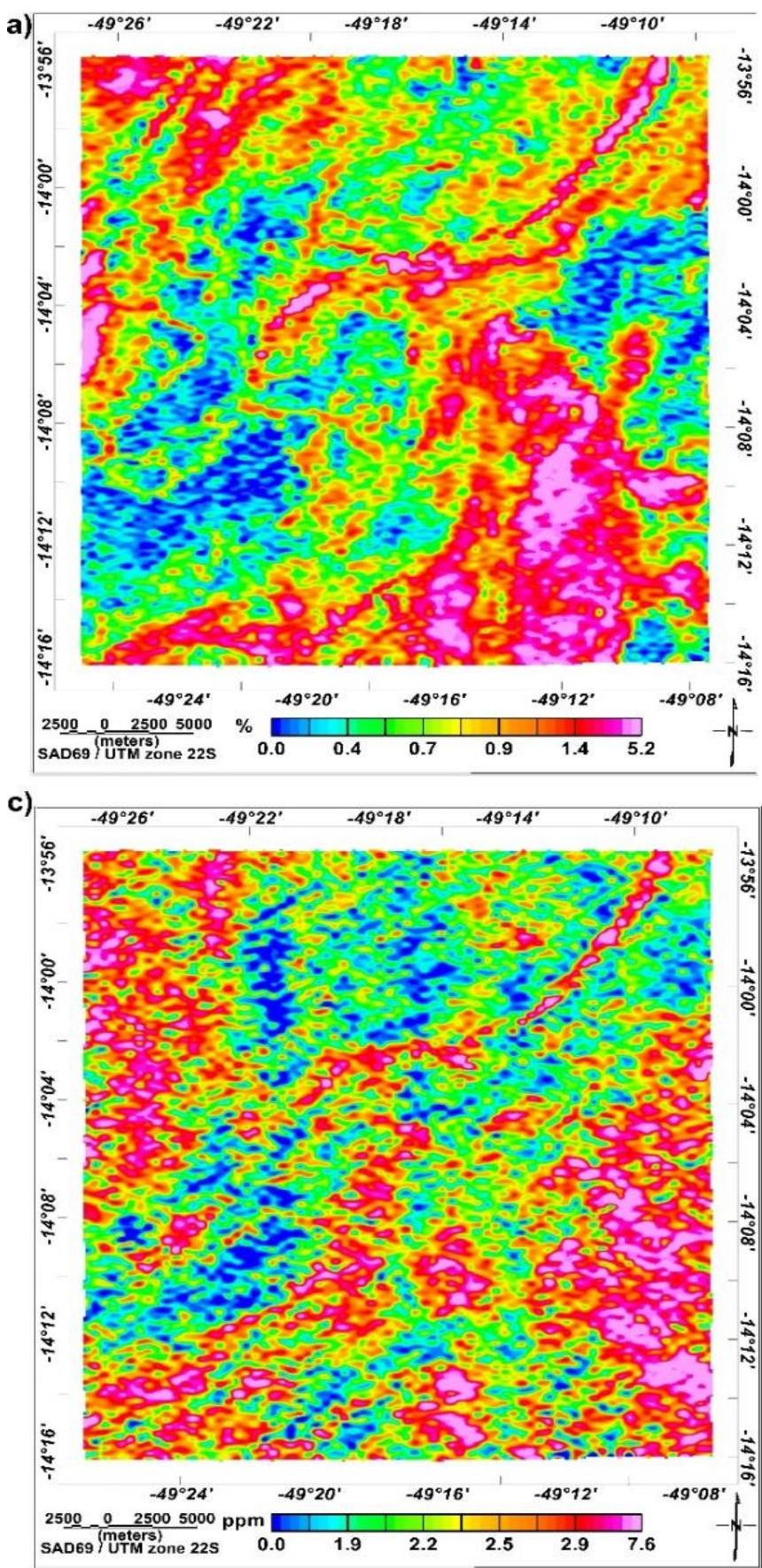

related to the high, medium and low concentrations, respectively.

In an ideal dataset, the low, medium and high values combination of the $\mathrm{K}$, eTh and eU would result in a 27 classes division. However, due to the inherent variability of the study area data, only 24 classes were generated.

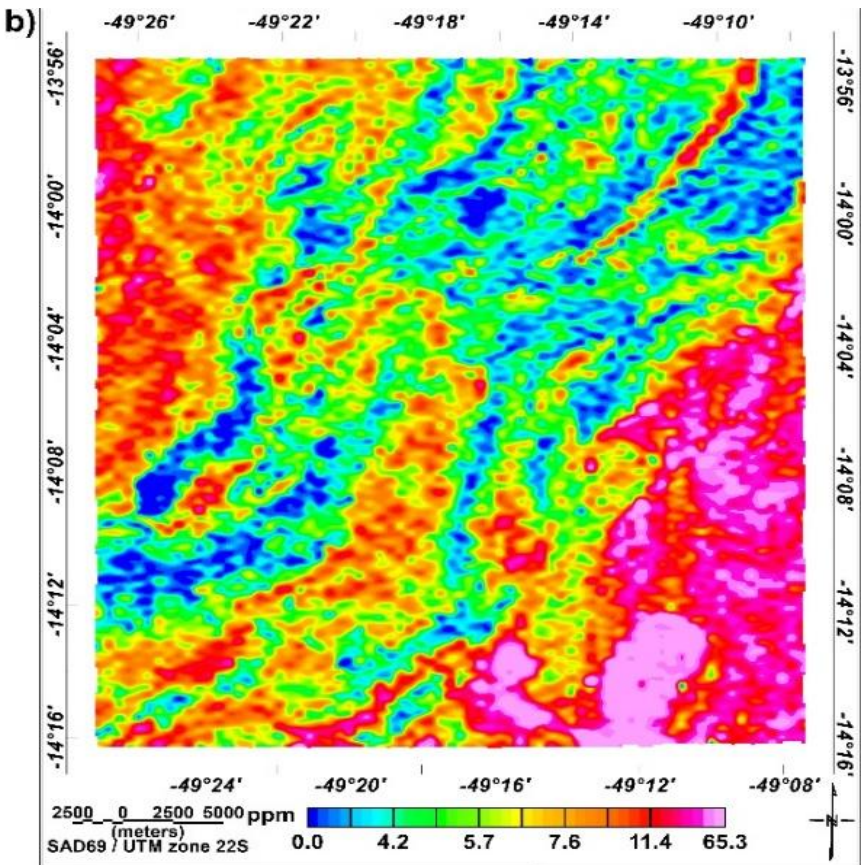

d)

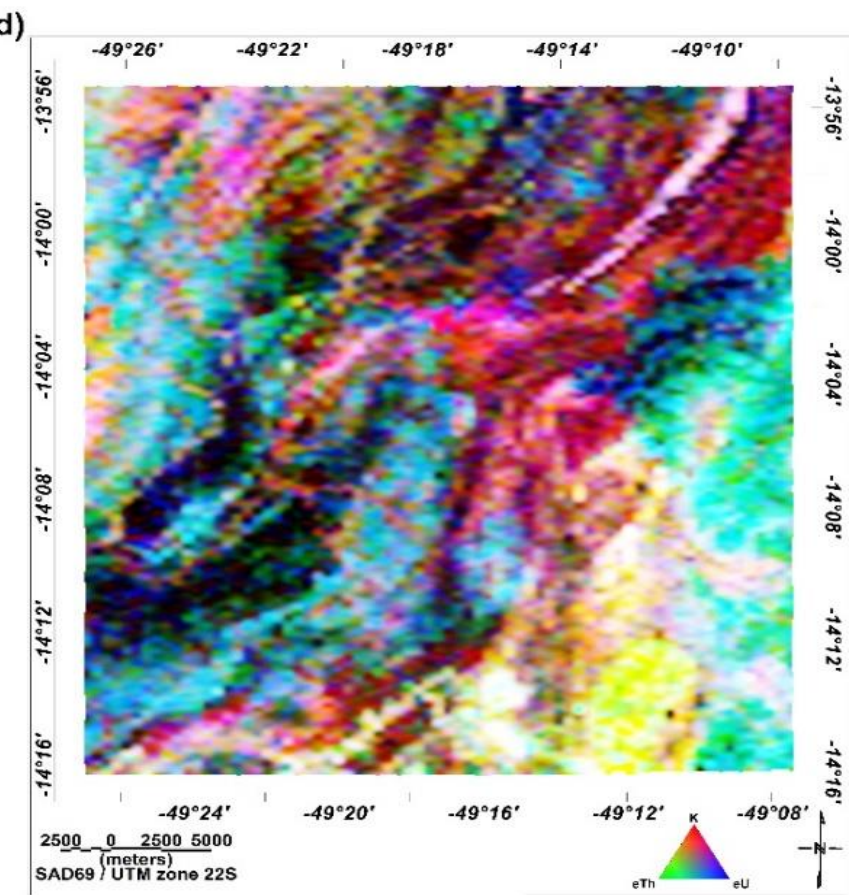

Figure 4- Gama-ray spectrometry maps: a) Potassium, b) Thorium, c) Uranium and d) Ternary 
The classes were named according to the classification in figure 3, where numbers 1, 2 and 3 indicates low, medium and high values, respectively, of potassium, thorium and uranium, in this order. The resulting products from the manual classifications and the LGM software can be compared in figure 5.

The comparison between the two final products revealed that the results overlap with very small differences related to method resolution (Fig.5), which could be adjusted in later versions. The similarity of the resulting maps validates the results obtained by the LGM.

The analysis of the lithogeophysical map generated by LGM was based on the main geological units overlap of the research area, from where it was possible to verify some correspondence relations.

The lithogeophysical map presents predominantly average values for all elements (class 222 for $\mathrm{K}$, eTh and eU), but anomalies are observed in specific places.

Related to the Mara Rosa Sequence (Fig. 6a) are observed low potassium values (122 to 132 classes) in its midwest and east portions, respectively composed of micaxists and a set of ultramafic rocks, chlorite schists and magnetite schists.

In the western portion of the sequence, medium values of potassium and thorium and high uranium (class 223) are observed. This region is composed of alumina schists, meta-tuffs and metagraywacke. These values can also be found in the southern portion which composed by metavolcanic felsic rocks at the northern portion.
The high potassium classes (321 to 323 ) are seen in the central and southern part of the research area, which are mainly composed of amphibolite schist, lapili-tuffs and meta-tuffs. At the northeast end of the area, an NE trend with high values is related to muscovite, quartzite and schist.

The classes related to granitic bodies (Fig. 6b) range from low potassium, medium thorium and high uranium (class 123) to all high-grade classes (333). The classes distribution is heterogeneous and varies between granitic bodies of the same suite.

The classes with lower values (123 to 222) are predominantly related to larger bodies located in the south portion of the area. Smaller bodies with the same signature are observed to the east and to the north of these intrusions.

Another granite signature is observed in the granitic bodies located in the northwest and centre of the area. Classes related to these bodies can range from 222 to 322 . High potassium values (322 to 333 ), are located in the area centre.

The orthogneisses unit (Fig. 6c) shows more heterogeneity in class distribution, involving practically the whole set of defined classes. Lower potassium values (classes 123 to 223) are located in the north central portion of the area. Classes higher values are observed in the southern portion, one in the northeast and the other in the northwest. The southern portion is related to kinzigites, biotite gneisses, migmatites and anatexy porphyritic granites. The northern areas are associated with the gneisses, tonalites and granites a)

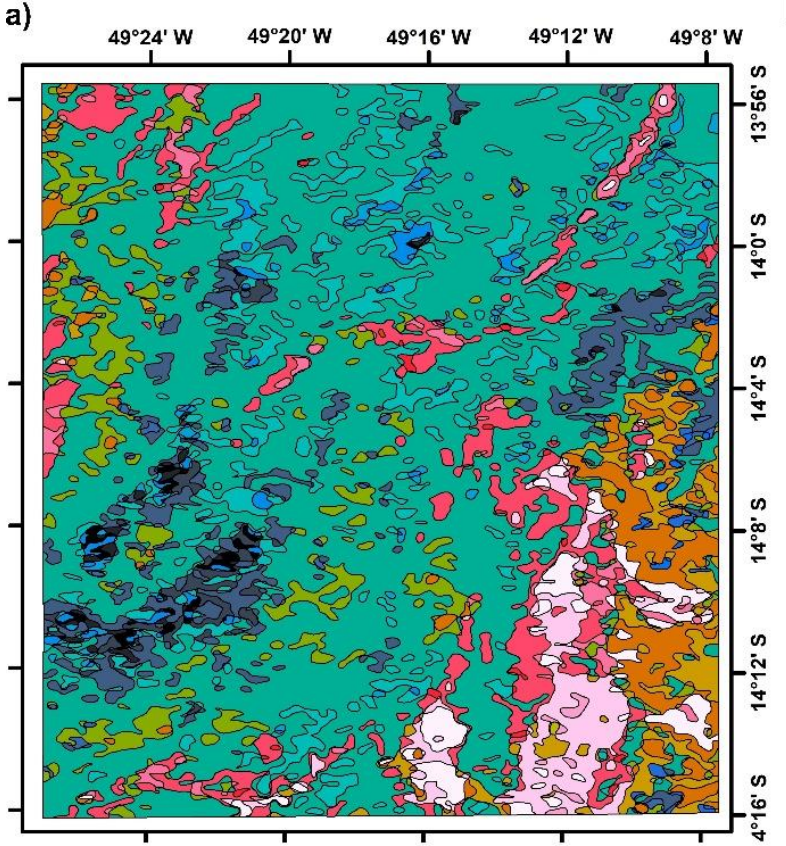

b)

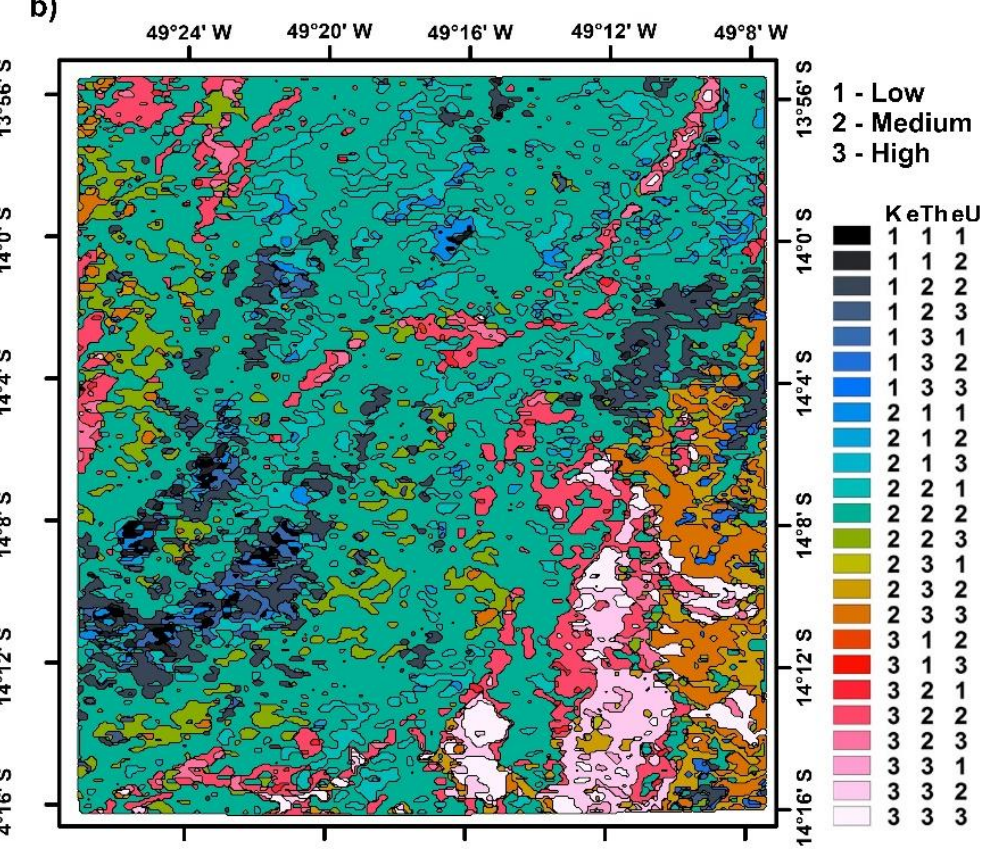

Figure 5 - Lithogeophysical maps of the study area. a) Standard procedure for statistical analysis, b) LGM statistical analysis. 

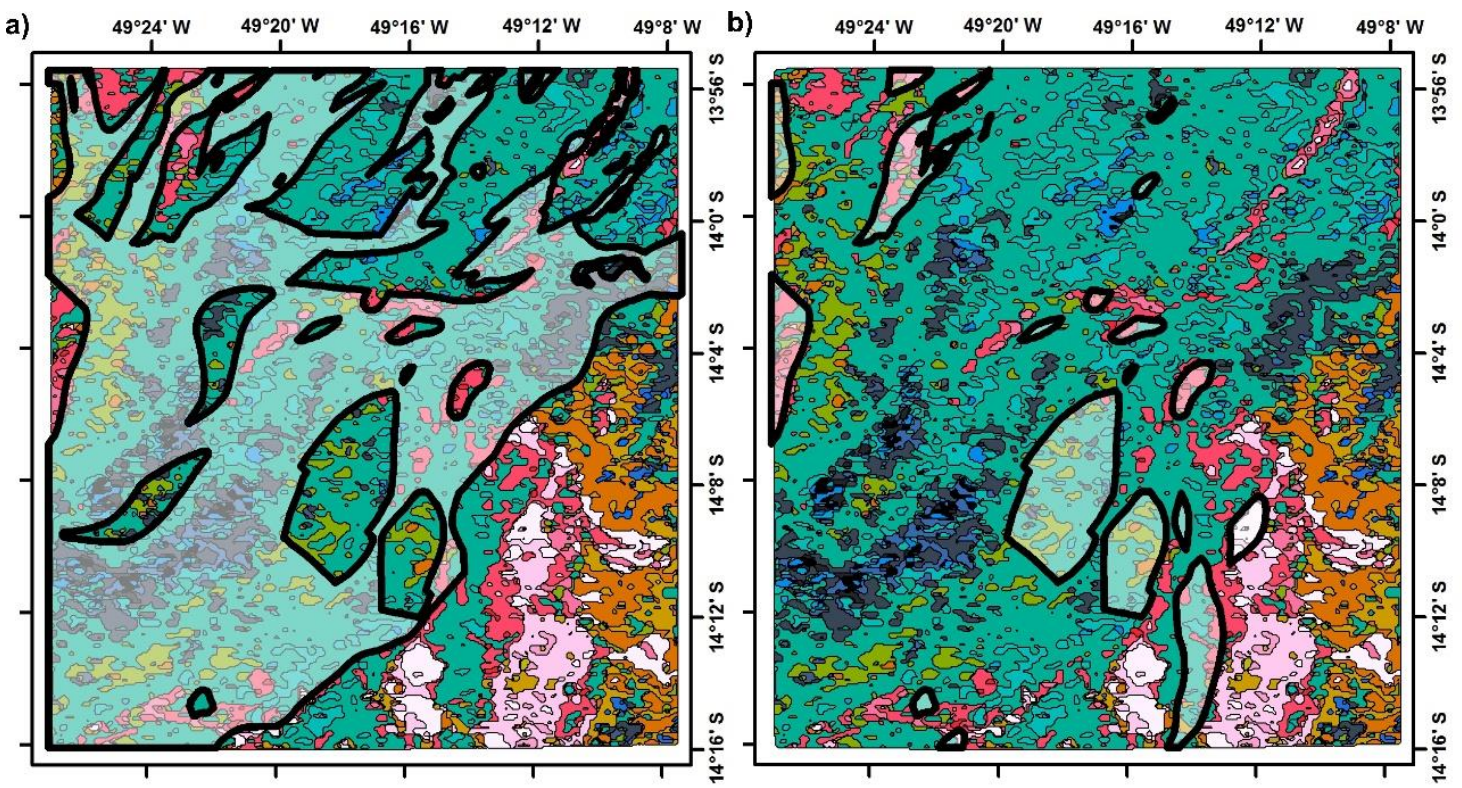

c) $\quad 49^{\circ} 24^{\prime} \mathrm{W} \quad 4^{\circ} 20^{\prime} \mathrm{W} \quad 49^{\circ} 16^{\prime} \mathrm{W} \quad 49^{\circ} 12^{\prime} \mathrm{W} \quad 49^{\circ} 8^{\prime} \mathrm{W} \quad$ d)

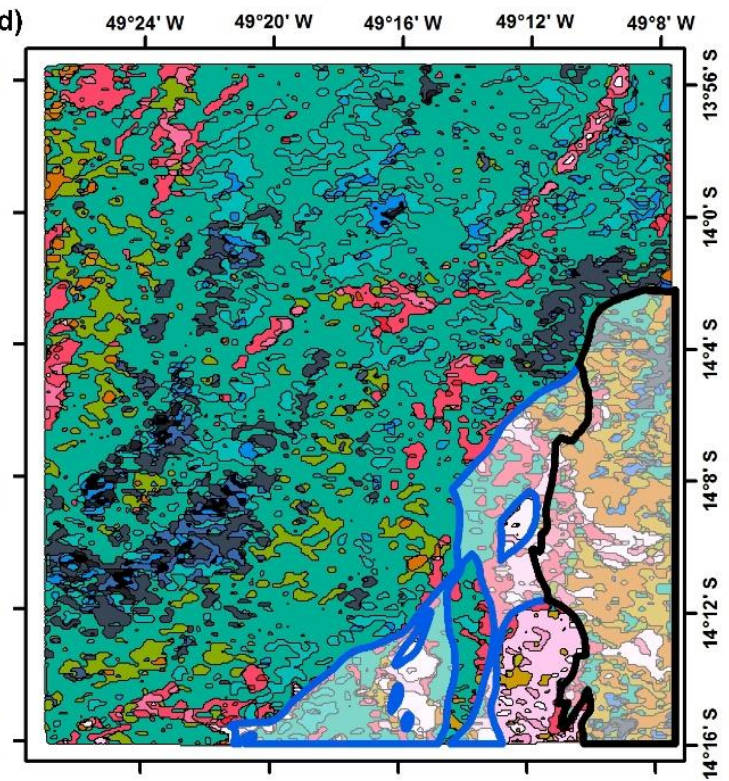

\section{1 - Low \\ 2 - Medium \\ 3 - High}
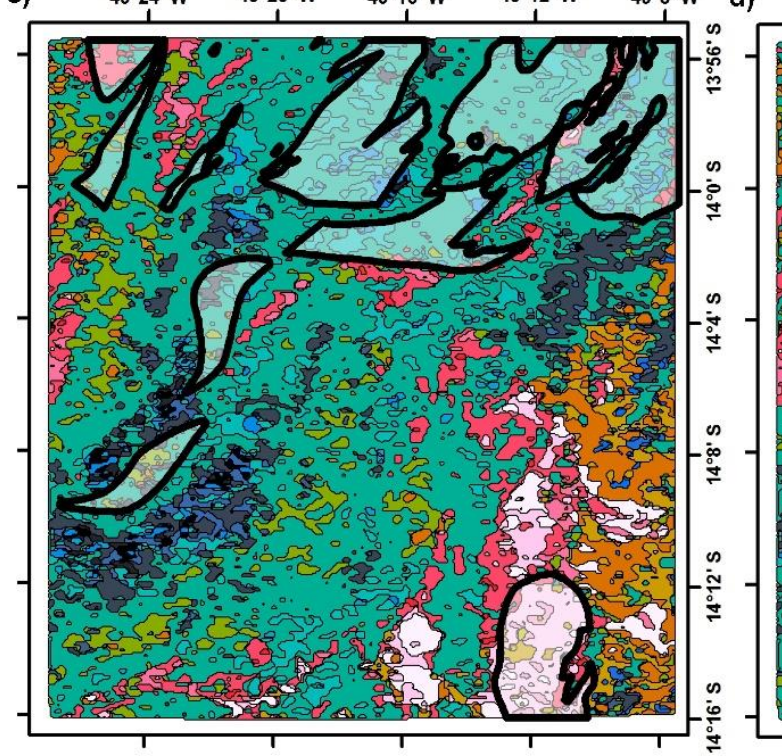

Figure 6 - Lithogeophysical maps with a transparency geology layers (black and blue edges). a) Mara Rosa Volcano Sedimentary Sequence; b) Sin - Pos Tectonic Granites; c) Orthogneiss - Biotite Gneiss and d) Serra da Mesa Group and Campinorte Volcano-Sedimentary Sequence.

The Campinorte Volcano-sedimentary Sequence (Fig. 6d), highlighted in blue, shows a large compositional variation, ranging from classes 122 to 333 .

The Campinorte Sequence consists of quartzites and a wide variety of mica schists. Within this larger unit are observed three smaller units (meta-rhyodacite, metarhyolite and schists), that apparently are related to the radioelements highest values. In these units, the predominant classes are 332 and 333.

The Serra da Mesa Group (Fig. 6d), highlighted in black, has a particular signature that differs from all geological units in the area. It has a large variety of classes (122 to 333), and have predominance in classes 232 and 233, associated with high thorium. These classes may be related to the carbonate schist of the meta-psamo-pelitic unit.

In the western and southeastern portions of Serra da Mesa Group (Fig. 6d), classes with high potassium and thorium are observed, with mean and high uranium values related to a quartzitic unit composed by quartzites and schists of varied composition.

\section{Conclusions}

The present study showed that through the use of LGM program, implemented in Matlab, it is possible to perform a lithogeophysical classification based on a statistical analysis of the gamma-ray spectrometric data, in an automated way. The final classification product has a direct correspondence with the analogous product generated by 
the statistical analysis and manual class separation through geoprocessing tools.

In this way, the main goal of the present work was to verify the method applicability in the analysis and creation of lithogeophysical maps.

\section{Acknowledgments}

The authors thank to Geological Survey of Brazil (CPRM), specially to the V.S. Oliveira CPRM/SUREG/MA for her contributions. F.R. Castro, J.D. Weihermann and L.G. Castro were supported in this research by fellowships from Fundação Capes, Ministério da Educação. F.J.F. Ferreira S.P. Oliveira and A.M. Silva were supported in this research by National Council for Scientific and Technological Development (CNPq, Brazil) (contracts $303826 / 2018-5, \quad 306978 / 2015-6$ and 307177/2014-9 respectively).

\section{References}

ARANTES, D., BUCK, P.S., OSBOURNE, G.A., PORTO, C.G. A Sequência Vulcanosedimentar de Mara Rosa e Mineralizações Auríferas Associadas. Boletim Informativo da SBG, Núcleo Centro-Oeste, 27-40, 1991.

CASTRO, F. R., OLIVEIRA, S. P., DE SOUZA, J. \& FERREIRA, F. J. F. GRAV-MAG SUITE: An open source MATLAB-based program for processing potential field data. In: 8 Simpósio Brasileiro de Geofísica. Volume 1, SBG, Brazil. 2018.

CHARBONNEAU, B.W. Geochemical evolution and radioactive mineralogy of the Fort Smith radioactive belt, Northwest Territories, Canada. Primary Radioactive Minerals (The Textural Patterns of Radioactive Mineral Paragenetic Associations). Theophrastus Publications, Athens, Greece, pp. 21-48, 1991.

CPRM. Levantamento aerogeofísico do Estado de Goiás - Arco Magmático de Mara Rosa - Relatório Final, Volume I - Texto Técnico, 2004.

DELLA GIUSTINA, M. E. S. Geologia e geocronologia da sequência Vulcano-sedimentar Campinorte e do Complexo Uruaçu, província Tocantins. Dissertação de Mestrado - Universidade de Brasília, Brasília. 106pp, 2007.

DICKSON, B.L. \& SCOTT, K.M. Interpretation of aerial gamma-ray surveys - adding the geochemical factors. AGSO J. Aust. Geol. Geophys. 17 (2), 187-200, 1997.

GRAHAM, D.F., BONHAM-CARTER, G.F. Airborne radiometric data: a tool for reconnaissance geological mapping using a GIS. Photogram. Eng. Remote. Sens. 58 (8), 1243-1249, 1993

IAEA. Guidelines for Radioelement Mapping Using Gamma Ray Spectrometry Data.Technical Report Serie, $\mathrm{n}^{\circ}$ 1363. International Atomic Energy Agency, Vienna. 179 pp., 2003.

MINTY, B.R.S. Fundamentals of airborne gamma-ray spectrometry. AGSO J. Aust. Geol. Geophysics. 17 (2), 39-50, 1997.
OLIVEIRA V.S. Interpretação geofísico-geológica de uma porção setentrional do Cráton Amazônico. Dissertação de mestrado - Universidade Federal do Paraná. 115p, 2018.

SILVA, A.M., OLIVEIRA, C.G., MARQUES, G.C., PIRES, A.C.B. Geophysical responses of hydrothermal rocks associated with copper-gold mineralization in the Neoproterozoic Mara Rosa Magmatic Arc, central Brazil. In:Proceedings of the fifth decennial international conference on mineral exploration, 2,1179-1183, 2007.

PIMENTEL, M. M. The tectonic evolution of the Neoproterozoic Brasília Belt, central Brazil: a geochronological and isotopic approach. Brazilian Journal of Geology, 46, 67-82. 2016.

PIMENTEL, M.M., WHITEHOUSE, M.J., VIANA, M.G., FUCK, R.A., MACHADO, N. The Mara Rosa Arc in the Tocantins Province:further evidence for Neoproterozoic crustal acretion in central Brazil. Precambrian Research, 81. p.299-310, 1997.

WILFORD, J.R., BIERWIRTH, P.N., CRAIG, M.A. Application of airborne gamma-ray spectrometry in soil/regolith mapping and applied geomorphology. AGSO J. Aust. Geol. Geophysics. 17 (2), 201-216, 1997.

WILFORD, J. Airborne gamma-ray spectrometry. In: Papp (Ed.), Geophysical and Remote Sensing Methods for Regolith Exploration. CRCLEME Open File Report 144, pp. 46-52, 2002. 